\title{
Tricyclic Neovibsanin Scaffold Inhibits Glioma by Targeting Glioma-Initiating Cells
}

\author{
Peng Ding ${ }^{1,2}$, Xi-Miao $\mathrm{Xu}^{3}$, Liang-Zhu Teng ${ }^{1}$, Ji-Jun $\mathrm{Xu}^{2}$ and $\mathrm{Xu}-\mathrm{Yuan} \mathrm{Zhao}^{2 *}$ \\ ${ }^{1}$ Department of Neurosurgery, Shandong Provincial Hospital, Shandong University, Jinan, Shandong, 250021, ${ }^{2}$ Department of \\ Neurosurgery, ${ }^{3}$ Department of Medical Imaging, Tengzhou Central People's Hospital, Tengzhou, Shandong, 277599, China \\ *For correspondence: Email: zhaoxuyuanews@hotmail.com; Tel/Fax: 0086-632-5511021
}

\begin{abstract}
Purpose: To investigate the effect of tricyclic neovibsanin scaffold (TCNS) on cell viability, colony formation capacity and induction of apoptosis in glioma cells.

Methods: 3-(4, 5-Dimethylthiazol-2-yl) 2, 5-diphe-nyltetrazolium bromide (MTT) assay was used to analyze the effect of TCNS on cell proliferation. Light microscopic examination of giemsa solution stained cells was used to calculate the number of colonies with >50 cells. Flow cytometry using a flow cytometer, while apoptosis detection kit were used to analyze induction of apoptosis.

Results: TCNS treatment significantly inhibited the viability of U138 NS and U138 AC cells in a concentration-dependent manner $(p<0.05)$. TCNS caused $86 \%$ reduction in the capacity of U138 NS cells to form colonies and led to significant induction of apoptosis. The activation of caspase 3 and expression of Bax was increased significantly $(p<0.05)$. Moreover, TCNS treatment increased the median survival time of mice bearing glioma to 34 days compared to 22 days in untreated mice.

Conclusion: Thus, TCNS treatment significantly inhibits the viability of glioma cells and colony formation, but induces apoptosis and increases the median survival of mice. Hence, TCNS may be of therapeutic value for the treatment of glioma.
\end{abstract}

Keywords: Glioma, Tricyclic neovibsanin scaffold, Survival time, Colony formation, Apoptosis

Tropical Journal of Pharmaceutical Research is indexed by Science Citation Index (SciSearch), Scopus, International Pharmaceutical Abstract, Chemical Abstracts, Embase, Index Copernicus, EBSCO, African Index Medicus, JournalSeek, Journal Citation Reports/Science Edition, Directory of Open Access Journals (DOAJ), African Journal Online, Bioline International, Open-J-Gate and Pharmacy Abstracts

\section{INTRODUCTION}

Glioma is the most frequently detected primary brain tumor in adults and has a median survival time of around 3 months for patients availing no treatment [1]. The currently used treatment strategies for glioma, include chemotherapy, radiotherapy and surgical resection. However, because of the enhanced rate of proliferation and aggressive invasive and metastasis potential the rate of glioma prognosis is very poor. Glioma initiating cells (GICs) comprise a group of cells which are associated with beginning and progress of brain tumor [2 3]. These cells are bestowed with the capacity of self-renewal and multiplication. GICs are resistant to various anticancer agents, leading to the failure of cancer treatment strategies [4,5]. Therefore the development of novel and efficient treatment strategies for glioma inhibition are required [610].

Neovibsanins are diterpenoid compounds present in plants and possess polyfunctional structures. They were isolated by Fukuyama's research group in 1996 during photochemical investigation of the extract of the shrub, Viburnum awabuki [11]. Later, these compounds were found to promote neurite outgrowth activity in PC12 cells. Therefore, it is believed that 
neovibsanin-type compounds can be of vital importance for the treatment of neurological disorders, including Alzheimer's disease [12]. It was observed that not only neovibsanins but also their synthetic derivatives exhibit neurite outgrowth activities. There is hardly any effect of stereochemistry on the biological activity of neovibsanins [13]. The tricyclic neovibsanin scaffold showed neurite outgrowth activity similar to that of the parent neovibsanin [14]. The present study was performed to investigate the effect of tricyclic neovibsanin scaffold (Figure 1) on cell proliferation, colony formation capacity and induction of apoptosis in glioma cells. It was observed that TCNS inhibits cell proliferation and colony formation and induces apoptosis in glioma cells.

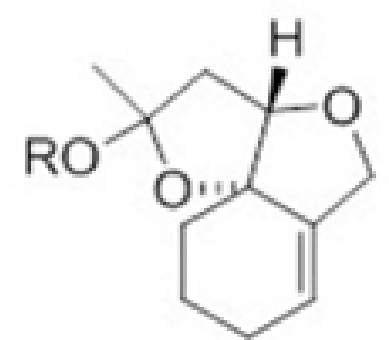

Figure 1: Structure of tricycle neovibsanin scaffold (TCNS)

\section{EXPERIMENTAL}

\section{Animals}

A total of $10 \mathrm{BALB} / \mathrm{c}$ mice, 8 - 10 week old and $22 \pm 2 \mathrm{~g}$ in weight were purchased from the Experimental Animal Center of Shandong University (Jinan, China). The animals were acclimatized to the laboratory conditions one week before the start of experiment and were maintained at $24{ }^{\circ} \mathrm{C}$ with free access to water and standard laboratory chow. All the experimental procedures were performed according to the guidelines of Laboratory Animal Care Committee of Sun Yat-sen University (Guangzhou, China). Approval was taken from the ethics and review committee for the animal studies at Laboratory Animal Care Committee of Sun Yat-sen University (approval ref no. 179 2008).

\section{Reagents}

Tricyclic neovibsanin scaffold (TCNS) was synthesized using the reported protocol [14] and dissolved in DMSO to prepare the stock solution. Fetal bovine serum (FBS) and Dulbecco's modified Eagle's medium (DMEM) were purchased from Life Technologies (Gaithersburg,
MD, USA). Dimethyl sulphoxide and other common chemicals were obtained from Sigma (St. Louis, MO, USA).

\section{Cell culture}

Glioma cell line, GL261 was purchased from Shanghai Institute of Biochemistry and Cellular Biology Chinese Academy of Sciences (Shanghai, China). The cells were cultured in Dulbecco's modified Eagle's medium supplemented with $10 \%$ fetal bovine serum and antibiotics. Then the cells were maintained in a humidified atmosphere at $37{ }^{\circ} \mathrm{C}$ with $5 \% \mathrm{CO}_{2}$ and $95 \%$ air.

\section{Immunocytochemistry analysis}

On to the poly L lysine coated coverslips cells were dispersed and the slides were fixed with paraformaldehyde. After $45 \mathrm{~min}$ normal goat serum was applied to block the cell samples followed by overnight incubation with anti-mouse CD133/1 monoclonal and GFAP polyclonal primary antibodies. The cells were subjected to Cy3 conjugated goat anti rabbit secondary antibody staining after washing with PBS. Following $45 \mathrm{~min}$ incubation the cells were counterstained using $100 \mathrm{mg} / \mathrm{mL}$ DAPI for 20 min. A confocal laser scanning microscope (Leica, Mannheim, Germany) was used for analysis of the cell nuclei.

\section{Assessment of cell viability}

For determination of cell viability colorimetric 3(4, 5-dimethylthiazol-2-yl) 2, 5-diphenyltetrazolium bromide (MTT) assay was used. Briefly, the cells at a density of $2 \times 10^{5}$ cells per well were dispersed onto 96 well culture plates and treated with various concentrations of TCNS for $24 \mathrm{~h}$. After incubation, the cells were rinsed two times in phosphate buffered saline (PBS) followed by incubation for $4 \mathrm{~h}$ with MTT (5 $\mathrm{mg} / \mathrm{mL})$. Dimethyl sulphoxide $(150 \mu \mathrm{l})$ was added to each well for dissolving the insoluble blue formazan crystals formed. Absorbance was measured for each well at $565 \mathrm{~nm}$ with an enzyme linked immunosorbent assay plate reader (DR-200Bs; Bio Rad Laboratories, Hercules, CA, USA).

\section{Colony formation assay}

In order to determine the effect of TCNS on the capacity to form colonies, the cells were distributed at a density of $2 \times 10^{5}$ cells per $\mathrm{ml}$ on to 12-well plates. The cells were exposed to TCNS, taxol or DMSO and incubated for 5 days. After incubation, the cells were subjected to 
crystal violet solution staining and the number of colonies formed was counted using an Olympus CX22 microscope (Olympus Corp, Inc, Tokyo, Japan).

\section{Flow cytometric analysis of apoptosis}

The cells after treatment with TCNS were harvested using trypsinization and rinsed in phosphate buffered saline twice. The cells were then re-suspended in binding buffer at a concentration of $2.5 \times 10^{6}$ cells per $\mathrm{mL}$, and $5 \mu \mathrm{L}$ each of annexin-V-fluorescein isothiocyanate (FITC) and propidium iodide (PI) were added to the cell suspension and incubation was continued for 15 min under dark atmosphere. FACScalibur Flow Cytometer (BD Biosciences, San Jose, CA, USA) was used to measure the apoptotic cell percentage.

\section{Western blot analysis}

TCNS treated cells were harvested and washed twice with PBS. The cells were the lysed for 40 min in lysis buffer (50 mM Tris, pH 7.4, $1 \%$ Triton X 100, $150 \mathrm{mM} \mathrm{NaCl}, 1$ mM EDTA, 1 mM phenylmethylsulfonyl fluoride, $1 \mathrm{mM}$ ethylene glycol tetraacetic acid, $10 \mu \mathrm{g} / \mathrm{mL}$ aprotinin, $1 \mathrm{mM}$ sodium orthovandate, $10 \mu \mathrm{g} / \mathrm{mL}$ leupeptin and 1 $\mathrm{mM} \mathrm{NaF}$ ). Cell lysates were centrifuged at $12,000 \times \mathrm{g}$ for $45 \mathrm{~min}$ at $4{ }^{\circ} \mathrm{C}$. Electrophoresis using $10 \%$ sodium dodecyl sulfate polyacrylamide gel was used to resolve the proteins from each sample. The proteins were transferred onto a nitro-cellulose membrane and incubated with primary antibodies using blocking buffer. After incubation with primary antibodies the membrane was washed again with PBS. The membrane was then incubated with horseradish peroxidase conjugated goat anti-rabbit IgG (Wuhan Boster Biological Technology, Ltd) secondary antibodies. $\beta$-actin was examined on the same membrane and used as a loading control. The electrochemiluminesence reagent (GE Healthcare, Amersham, UK) was used to detect the antibody bound complexes. Optical density (OD) was determined for the relative levels of the target protein.

\section{Xenograft tumor formation assays}

TCNS treated and control cells were harvested and suspended in $200 \mu \mathrm{L}$ of sterile saline at a density of $2 \times 10^{6}$ cells. Among two groups of mice with 5 mice in each group, one group was administered TCNS treated cells and the second group untreated cells subcutaneously. After 2 months of administration of cells, the survival time of the mice was compared.

\section{Statistical analysis}

All the data are expressed as mean $\pm \operatorname{SD}(n=3)$. One way analysis of variance and SPSS 16.0 software (SPSS, Inc., Chicago, IL, USA) were used for the analysis of differences in data. Differences were considered significant statistically at $p<0.05$.

\section{RESULTS}

\section{U138 NS and U138 AC cells}

U138 cells were induced to form neurospheres by culturing in a medium devoid of serum and containing basic fibroblast growth factor, epidermal growth factor, L glutamine and insulin. Formation of neurospheres was evident by the presence of CD133 cell marker (Figure 2). Differentiation was induced by replacing the media every 4 days with DMEM supplemented with $10 \%$ FBS. It was observed that the cells got adhered and started to differentiate forming U138 AC cells.

\section{CD133}

GFAP
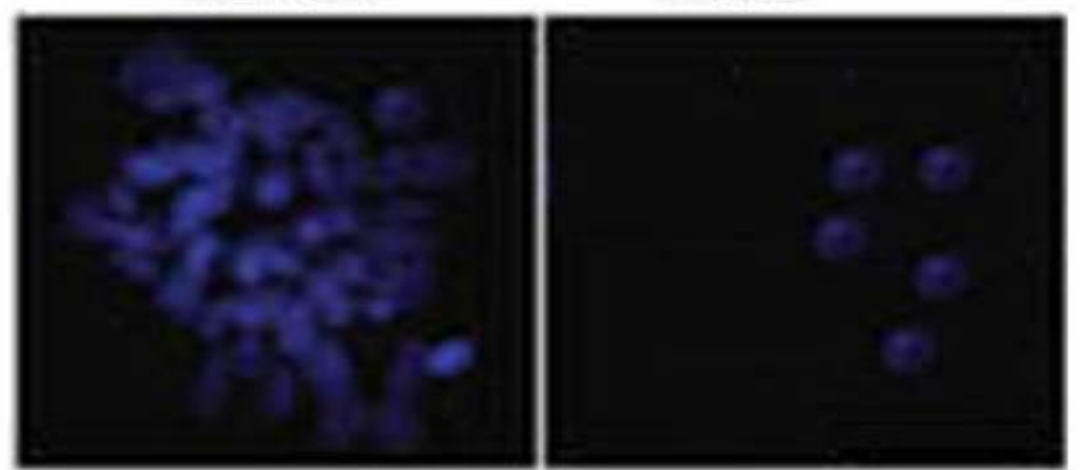

Figure 2: Preparation of U138-NS and U138-AC cells. Cells showing expression of CD133 marker on immunofluorescence 


\section{Inhibition of U138 NS and U138 AC cell viability by TCNS}

The results of MTT assay revealed that TCNS treatment inhibited the viability of U138 NS and U138 AC cells in concentration dependent manner.

Among the range of TCNS concentrations from 1 to $10 \mu \mathrm{M}$ used the minimum inhibitory concentration of TCNS against U138 NS and U138 AC cells was 4 and $6 \mu \mathrm{M}$, respectively (Figure 3).

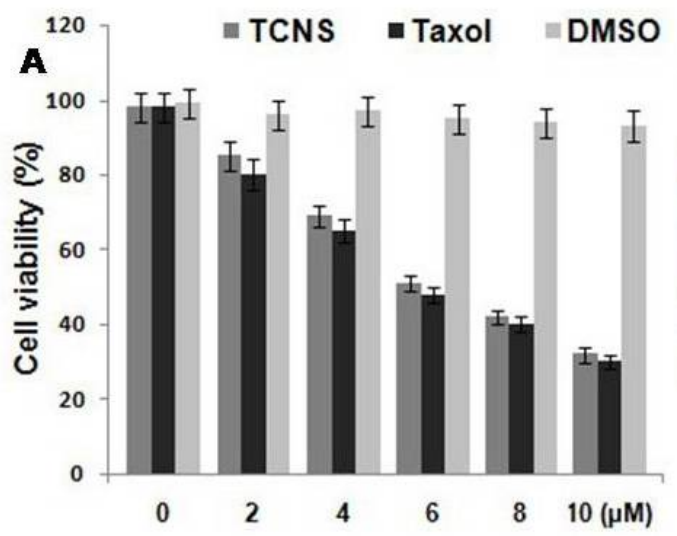

Inhibition of colony formation in U138 NS cells by TCNS

Exposure of U138 NS cells to $5 \mu \mathrm{M}$ concentration of TCNS for 5 days caused a significant decrease in the capacity to form colonies. Comparison of the inhibition in colony formation with taxol, a known anticancer agent revealed that TCNS at $5 \mu \mathrm{M}$ concentration exhibited similar inhibitory effect as that of taxol at $20 \mu \mathrm{M}$. The reduction in colony formation was 86,84 and $5 \%$ by TCNS, taxol and DMSO, respectively, after 5 days (Figure 4).

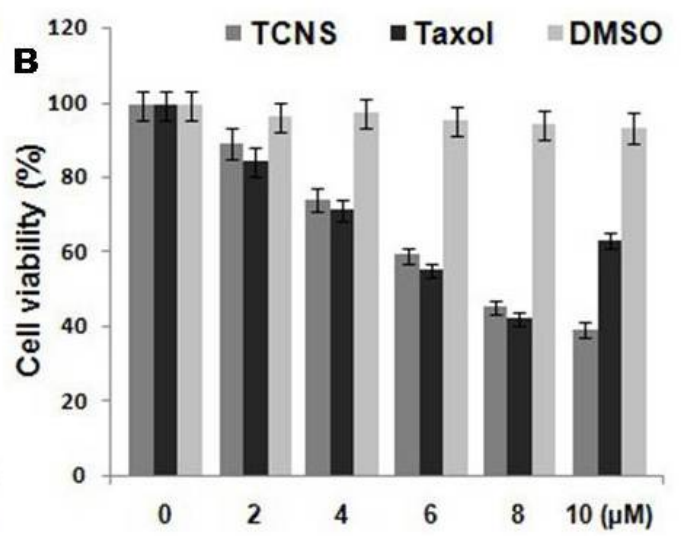

Figure 3: Inhibition of the viability of U138-NS and U138-AC cells by TCNS treatment. The cells after treatment with TCNS or DMSO as control was subjected to MTT assay

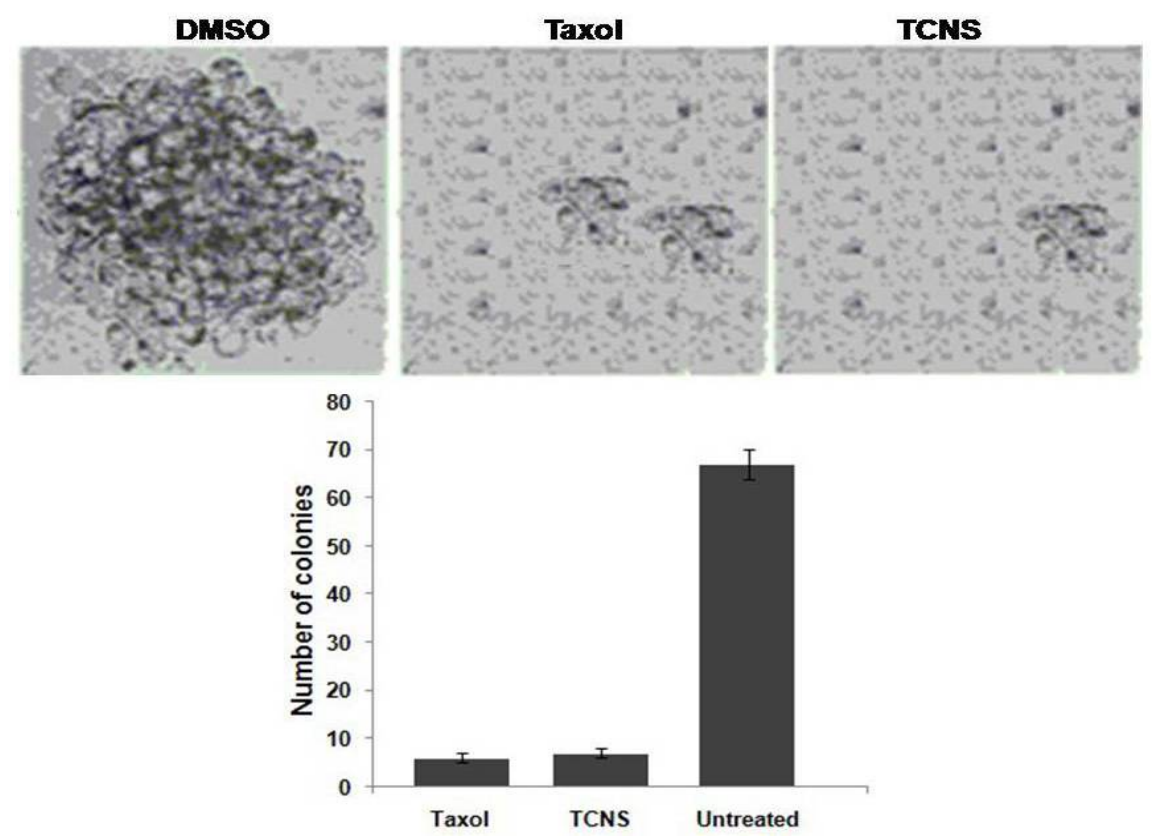

Figure 4: TCNS and taxol treatment inhibits the colony formation capacity of U138-NS cells after 5 days. The cells were treated with TCNS, taxol or DMSO for 5 days followed by analysis for colony formation. (A) Morphological appearances of colonies and (B) Colonies with more than 50 cells were counted hibition of the viability of U138-NS and U138-AC cells by TCNS treatment. The cells after treatment with TCNS or DMSO as control was subjected to MTT assay 
Induction of apoptosis in U138 NS cells by TCNS

Exposure of U138 NS cells to TCNS at $5 \mu \mathrm{M}$ concentration caused a significant increase in apoptotic cell population compared to the control cells $(p<0.05$; Figure 5A). The results from western blot analysis revealed that TCNS enhanced the activation of caspase 3 protein in U138 NS cells after $24 \mathrm{~h}$. TCNS also induced the expression of Bax protein significantly following $24 \mathrm{~h}$ treatment $(p<0.05$; Figure $5 \mathrm{~B})$. The increase in the activation of caspase 3 and expression of Bax in TCNS and taxol treated cells was similar.

\section{TCNS prolongs the median survival time of tumor bearing mice}

Examination of the median survival time of rats revealed that TCNS caused a significant increase in the median survival time of mice compared to the untreated rats. The median survival times were 34,33 and 22 days respectively for mice in normal, TCNS treated and untreated mice, respectively.

\section{DISCUSSION}

Glioma initiating cells (GICs) comprise a group of cells possessing the ability of self-renewal and recapitulation. Natural products play an important role in the development of chemopreventive and chemotherapeutic agents used for treatment of various cancers [15]. Neovibsanins are diterpenoid compounds present in plants and possess polyfunctional structures. They were isolated by Fukuyama's research group in 1996 during photochemical investigation of the extract of the shrub, Viburnum awabuki [11]. The present study was performed to investigate the effect of tricyclic neovibsanin scaffold on proliferation, colony formation, induction of apoptosis and increase in median survival of mice.

Cancer cells possess the ability to proliferate at an infinite rate, therefore, the inhibition of cell proliferation is an important treatment strategy for cancer therapy.
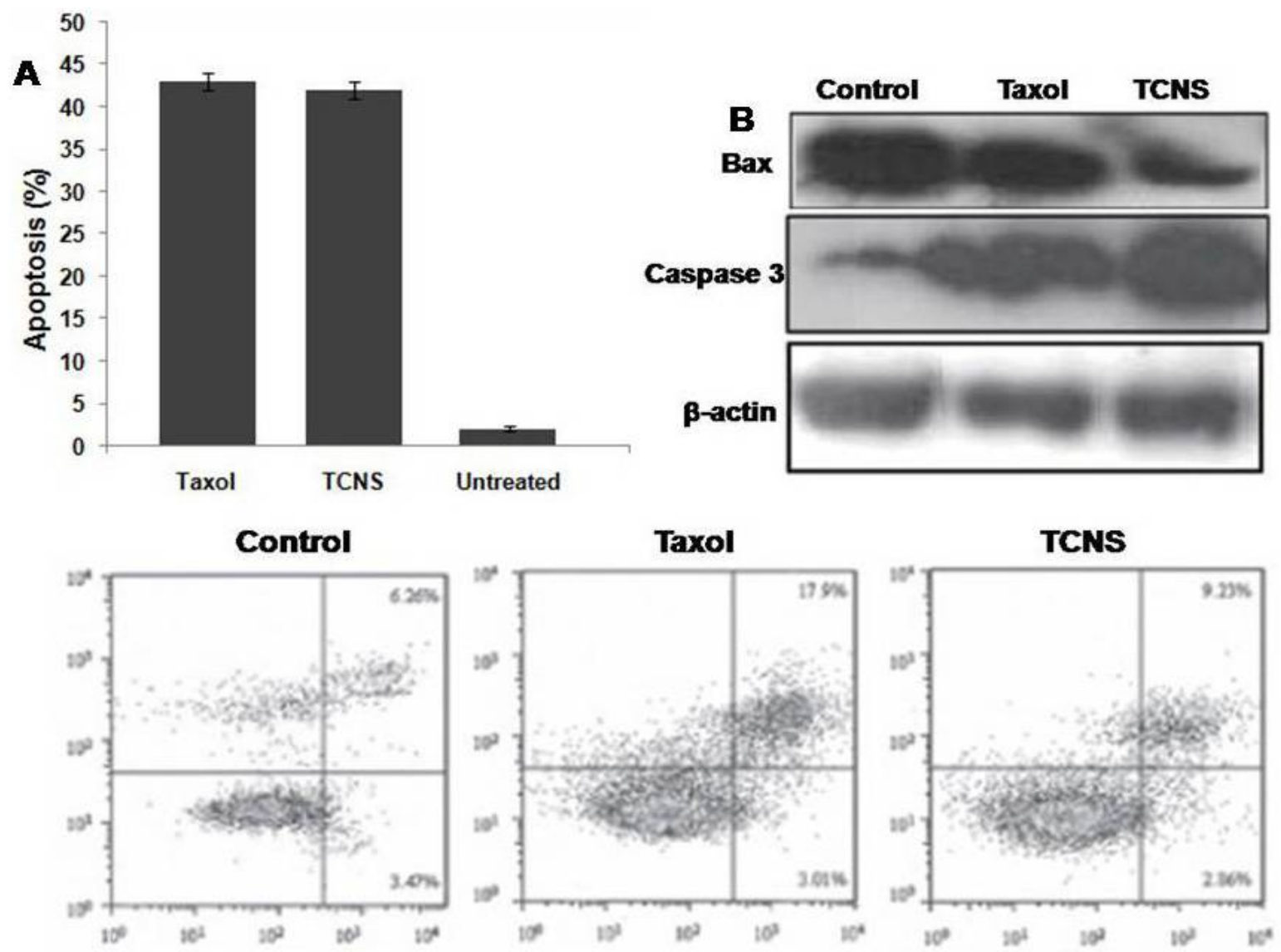

Figure 5: TCNS and taxol induce apoptosis in U138-NS cells after $24 \mathrm{~h}$. The cells after treatment with TCNS, taxol or DMSO were analysed by flow cytometry 
In the present study TCNS significantly inhibited the proliferation of glioma cells. Apoptosis is the programmed death of cells regulated by genes and imbalance between apoptosis and cell proliferation leads to various disorders, including carcinoma. Cancer cells are also resistant to apoptosis, and therefore, the induction of apoptosis in carcinoma cells by various agents can be of therapeutic importance for cancer treatment $[16,17]$. In the present study treatment of glioma cells with TCNS caused a significant increase in the induction of cell apoptosis.

For understanding the mechanism of TCNS induced apoptosis the expression of Bax and activation of cleaved caspase 3 were analyzed. Caspase 3 plays a vital role in the induction of cell apoptosis $[18,19]$. Activated Bax enters into the mitochondrial membrane leading to enhanced membrane permeability and release of cytochrome C [20]. Cytochrome C then binds with apoptotic protease activating factor 1 and ATP and ultimately results in an apoptotic cell [18]. In the present study, the levels of cleaved caspase 3 and Bax were significantly increased. Therefore, it was deduced that TCNS exerts its proapoptotic effects by increasing the levels of proapoptotic proteins. In addition, TCNS increases the median survival of mice significantly compared to the untreated mice.

\section{CONCLUSION}

TCNS significantly inhibits U138NS and U138AC cell viability, cell colony forming capacity, induces apoptotic cell death and increases median survival time of mice bearing glioma. Thus, TCNS may be of therapeutic importance in the treatment of malignant glioma.

\section{REFERENCES}

1. Ng SS, Gao Y, Chau DH. A novel glioblastoma cancer gene therapy using AAV-mediated long-term expression of human TERT C-terminal polypeptide. Cancer Gene Ther 2007; 14: 561-572.

2. Stiles $C D$, Rowitch $D H$. Glioma stem cells: a midterm exam. Neuron 2008; 58: 832846.

3. Vescovi AL, Galli R, Reynolds BA. Brain tumour stem cells. Nat Rev Cancer 2006; 6: 425436.
4. Natsume A, Kinjo S, Yuki K. Glioma initiating cells and molecular pathology: implications for therapy. Brain Tumor Pathol 2011; 28: 112.

5. Eramo $A$, Ricci-Vitiani L, Zeuner $A$, Pallini $R$, Lotti $F$, Sette G, Pilozzi E, Larocca LM, Peschle C, De Maria R. Chemotherapy resistance of glioblastoma stem cells. Cell Death Differ 2006; 13: 12381241.

6. Lin $Z X$, Yang LJ, Huang $Q$, Lin JH, Ren J, Chen ZB, Zhou LY, Zhang PF, Fu J. Inhibition of tumor-induced edema by antisense VEGF is mediated by suppressive vesiculo-vacuolar organelles (VVO) formation. Cancer Sci 2008; 99: 2540-2546.

7. Paez-Ribes M, Allen E, Hudock J. Antiangiogenic therapy elicits malignant progression of tumors to increased local invasion and distant metastasis. Cancer Cell 2009; 15: $220-231$.

8. Norden $A D$, Drappatz J, Wen PY. Novel anti-angiogenic therapies for malignant gliomas. Lancet Neurol 2008; 7: 1152-1160.

9. Vredenburgh JJ, Desjardins A, Herndon JN. Bevacizumab plus irinotecan in recurrent glioblastoma multiforme. J Clin Oncol 2007; 25: 4722-4729.

10. Tuettenberg J, Friedel C, Vajkoczy P. Angiogenesis in malignant glioma - a target for antitumor therapy? Crit Rev Oncol Hematol 2006; 59: 181-193.

11. Fukuyama Y, Minami H, Takeuchi K, Kodama M, Kawazu $K$. Neovibsanines $A$ and $B$, Unprecedented Diterpenes from Viburnum awabuki. Tetrahedron Lett. 1996; 37: 6767- 6770.

12. Fukuyama $Y$, Minami $H$, Yamamoto I, Kodama $M$, Kawazu K. Chem. Pharm. Bull. 1998; 46: 545-547.

13. Gallen MJ, Williams CM. Total Synthesis of ( \pm )-5,14-bisepi-Spirovibsanin A. Org. Lett. 2008; 10: 713-715.

14. Imagawa $H$, Saijo $H$, Kurisaki $T$, Yamamoto $H$, Kubo $M$, Fukuyama Y, Nishizawa M. Total Synthesis of ( \pm )Neovibsanin B. Org. Lett. 2009; 11: 1253-1255.

15. Franklin KBJ, Paxinos $G$ (Eds). The Mouse Brain in Stereotaxic Coordinates. 2nd edition. Academic Press, San Diego, 1997; pp 4995.

16. Warner TF. Apoptosis. Lancet 1972; 2: 1252.

17. Wyllie $A H$. The biology of cell death in tumours. Anticancer Res 1985; 5: 131-136.

18. Li $P$, Nijhawan $D$, Wang $X$. Mitochondrial activation of apoptosis. Cell 2004; 116: S57 S59.

19. Porter AG, Jänicke RU. Emerging roles of caspase-3 in apoptosis. Cell Death Differ 1999; 6: 99-104.

20. Luo X, Budihardjo I, Zou H. Bid, a Bcl2 interacting protein, mediates cytochrome $c$ release from mitochondria in response to activation of cell surface death receptors. Cell 1998; 94: 481-490. 